\title{
Pembuatan Surat Izin Usaha Perdagangan Bagi Perseroan Terbatas Dengan Terbitnya Peraturan Pemerintah Nomor 29 Tahun 2016
}

\author{
Anak Agung Bagus Putra Wibawa1 \\ ${ }^{1}$ Program Studi Magister (S2) Kenotariatan Fakultas Hukum Universitas Udayana, \\ E-mail: gunggusputra76@gmail.com
}

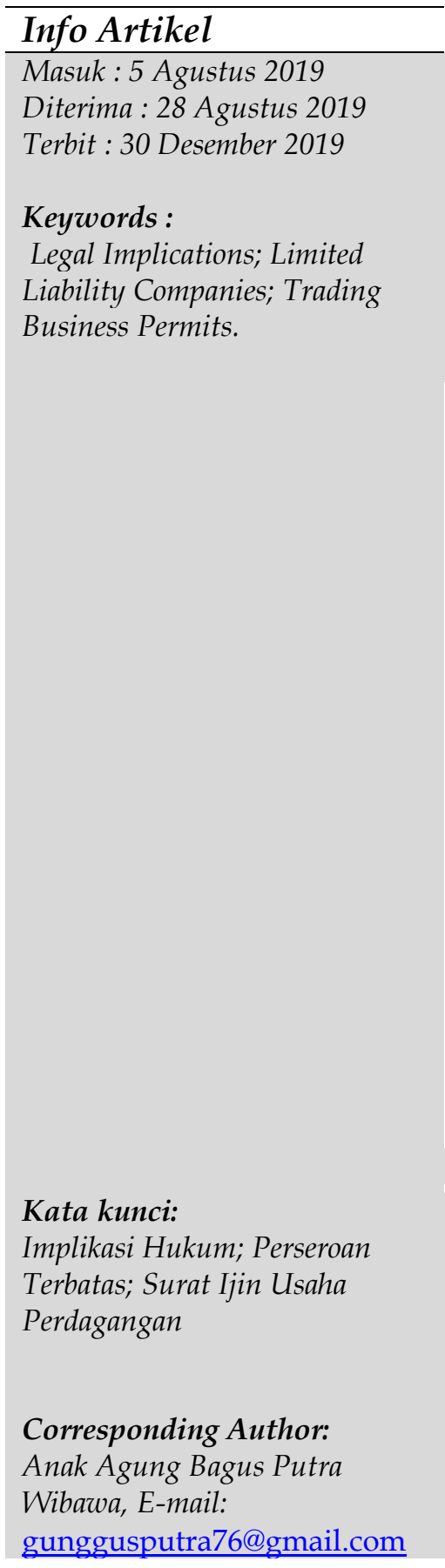

\begin{abstract}
The issuance of Government Regulation Number 29 Year 2016 concerning Changes in the Authorized Capital of Limited Liability has an impact on the founders of the company related to the cost reduction of the establishment of a Limited Liability Company which gives freedom to the founders of the company in determining the legal basis of a Limited Liability Company. Limited Liability Company is a company that carries out trading activities. Every company that carries out trading activities is obliged to take care of the Trade Business License. The making of Trade Business License is regulated in the Minister of Trade's Regulation No. 46 / M-DAG / PER / 9/2009 concerning Issuance of Trading Business License. One of the conditions is to have a wealth of $R p 50,000,000$ (fifty million rupiah). From this regulation arises a norm conflict between the Government Regulation and the Ministerial Regulation. The problems arising from this research are the process of establishing a limited company and how is the legal implication of establishing a limited company in making a trade business license with government regulation number 29 of 2016. This research is a normative study with a legal approach and a legal concept analysis approach. The process of establishing a limited liability company is by ordering the name of the company online, then making the deed of establishment of a Limited Liability Company with the conditions set. After all is fulfilled, then the registration is done online on the web https://www.ahu.go.id. the legal implications of establishing a Limited Company in making Trade Business License with Government Regulation Number 29 of 2016 is that the company's founder can make Trade Business License with an authorized capital based on the agreement of the company's founders.
\end{abstract}

Abstrak
Terbitnya Peraturan Pemerintah Nomor 29 Tahun 2016 tentang
Perubahan Modal Dasar Perseroan Terbatas berdampak pada
pendiri perseroan terkait keringanan biaya pendirian Perseroan
Terbatas (PT) yang memberikan kebebasan bagi para pendiri
perseroan dalam menentukan bersaran modal dasar Perseroan
Terbatas. Perseroan Terbatas merupakan perusahaan yang
didalamnya melakukan kegiatan perdagangan. Setiap perushaaan
yang melakukan kegiatan perdagangan wajib untuk mengurus
Surat Izin Usaha Perdangan (SIUP). Pembuatan SIUP diatur
dalam Perautran Menteri Perdagangan Republik Indonesia




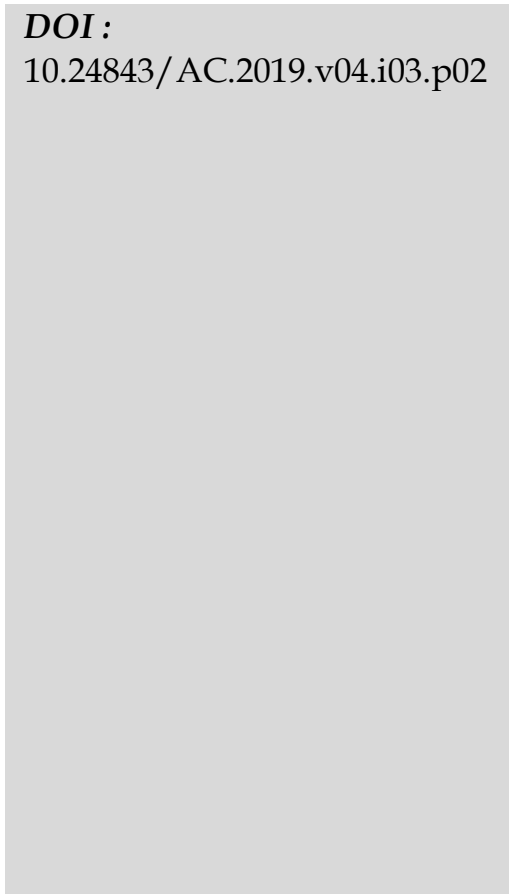

\begin{abstract}
Nomor 46/M-DAG/PER/9/2009 tentang Penerbitan Surat Izin Usaha Perdagangan. Salah satu syaratnya adalah memiliki kekayaan sebesar Rp 50.000.000, (lima puluh juta rupiah). Dari peraturan tersebut timbul konflik norma antara Peraturan Pemerintah dengan Peraturan Menteri tersebut. Adapun permasalahan yang timbul dari penelitian ini adalah Bagaimanakah Proses Pendirian Persoran Terbatas dan Bagaimanakah Implikasi Hukum Pendirian Perseoran Terbatas Dalam Membuat Surat Izin Usaha Perdagangan dengan Peraturan Pemerintah Nomor 29 Tahun 2016. Penelitian ini berupa penelitian normatif dengan pendeketan undang-undang dan pendekatan analisis konsep hukum. Peroses pendirian perseroan terbatas yaitu dengan memesan nama perseroan secara online, lalu pembuatan akta pendirian Perseroan Terbatas dengan syarat-syarat yang telah diatur. Setelah semua terpenuhi baru dilakukan pendaftarkan melalui online di web https://www.ahu.go.id. implikasi hukum pendirian Perseoran Terbatas dalam membuat SIUP dengan Peraturan Pemerintah Nomor 29 Tahun 2016 adalah pendiri perseroan dapat membuat SIUP dengan modal dasar kesepakatan para pendiri perseroan.
\end{abstract}

\title{
I. Pendahuluan
}

Perusahaan di Indonesia lebih dominan menjalankan usahanya dalam bentuk Perseroan Tersbatas (PT). Karena perseroan tersebatas merupakan gabungan dari modal para pendiri perseroan yang berbentuk badan hukum, dapat berdiri mandiri dengan tanggung jawab sebatas modal yang disetorkan saja. ${ }^{1}$ Perseroan terbatas atau istilah dalam bahasa Belanda disebut naamloze vennootschap, sedangkan dalam bahasa Inggris disebut company limited by shares, pada Pasal 1 ayat (1) Undang-Undang Nomor 40 Tahun 2007 tentang Perseroan Terbatas menjelaskan bahwa "Perseroan Terbatas, yang selanjutnya disebut Perseroan, adalah badan hukum yang merupakan persekutuan modal, didirikan berdasarkan perjanjian, melakukan kegiatan usaha dengan modal dasar yang seluruhnya terbagi dalam saham dan memenuhi persyaratan yang ditetapkan dalam undang-undang ini serta peraturan pelaksanaannya." Perseoran Terbatas sebagai badan hukum memiliki posisi yang setara dengan orang, terkait hak dan kewajiban sebagai subjek hukum. ${ }^{2}$ Sehingga pelaku usaha banyak tertarik untuk mendirikan Perseoran Terbatas, selain merupakan badan hukum, Perseroan Terbatas juga memiliki kelebihan-kelebihan dari pada badan usaha lainnya.

Kelebihan dari mendirikan Perseroan Terbatas salah satunya yaitu memiliki tanggung jawab yang terbatas, diatur dalam Pasal 3 ayat (1) Nomor 40 Tahun 2007 yang menjelaskan bahwa "Pemegang saham Perseroan tidak bertanggung jawab secara pribadi atas perikatan yang dibuat atas nama Perseroan dan tidak bertanggung jawab atas kerugian Perseroan melebihi saham yang dimiliki." Dengan demikian, para perseroan hanya bertanggung jawab dengan dana yang dikumpulkan dalam perseroan terbatas saja, tidak sampai ke kekayaan pribadi. Apabila perseroan memiliki hutang

\footnotetext{
${ }^{1}$ Simanjuntak, A. (2011). Prinsip-prinsip manajemen bisnis keluarga (family business) dikaitkan dengan kedudukan mandiri perseroan terbatas (PT). Jurnal manajemen dan kewirausahaan, 12(2), 113-120, hlm 113.

${ }^{2}$ Isfardiyana, S. H. (2015). Tanggung Jawab Direksi Perseroan Terbatas dalam Pelanggaran Fiduciary Duty. Padjadjaran Journal of Law, 2(1), hlm 169.
} 
lebih dari jumlah modal dasar, maka utang tersebut tidak sampai ke harta pribadi pemiliki perseoran. ${ }^{3}$

Namun dari kelebihan tersebut, Perseroan Terbatas memiliki kekurangan yaitu salah satunya adalah dalam hal pendirian perusahaan yang relatif lebih sulit, lama dan biayanya lebih besar. Dengan adanya permasalahan tersebut, pemerintah berupaya untuk memberikan kemudahan bagi pelaku usaha, terutama pelaku usaha yang baru memulai usahanya agar dapat semakin berkembang dan maju dengan diterbitkannya Peraturan Pemerintah Nomor 29 Tahun 2016 tentang Perubahan Modal Dasar Perseroan Terbatas modal dasar pendirian perseoran terbatas.

Terbitnya Peraturan Pemerintah Nomor 29 Tahun 2016 tentang Perubahan Modal Dasar Perseroan Terbatas berdampak pada para pendiri perseroan terkait keringanan pendirian Perseroan Terbatas (PT). Kemudahan yang diberikan atas Peraturan Pemerintah Nomor 29 Tahun 2016 adalah memberikan kebebasan bagi para pendiri perseroan dalam menentukan bersaran modal dasar Perseroan Terbatas. Ketentuan tersebut diatur dalam Perautran Pemerintah Pasal 1 ayat (3) Nomor 29 Tahun 2016 tentang Perubahan Modal Dasar Perseroan Terbatas yang menjelaskan bahwa "Besaran modal dasar Perseroan Terbatas sebagaimana dimaksud pada ayat (1) ditentukan berdasarkan kesepakatan para pendiri Perseroan Terbatas".

Sebelum berlakunya Peraturan Pemerintah Nomor 29 Tahun 2016 tentang Perubahan Modal Dasar Perseroan Terbatas, jumlah modal dasar yang disebutkan dalam akta pendirian Perseoran Terbatas diatur dalam Peraturan Pemerintah Nomor 7 Tahun 2016 tentang Perubahan Modal Dasar Perseroan Terbatas. Modal dasar pendirian diatur dalam Pasal 1 ayat (1) yang menjelaskan bahwa "Modal dasar Perseroan Terbatas paling sedikit Rp50.000.000,00 (lima puluh juta rupiah)". Peraturan tersebut dirasa memberatkan pelaku usaha pemula, sehingga pemerintah menerbitkan peraturan yang memberikan kemudahan bagi pelaku usaha dengan menerbitkan Peraturan Pemerintah Nomor 29 Tahun 2016. Pasal 1 ayat (2) Nomor 29 Tahun 2016 tentang Perubahan Modal Dasar Perseroan Terbatas menjelaskan "modal dalam Perseroan Terbatas harus dituangkan dalam anggaran dasar yang dimuat dalam anggaran dasar akta pendirian perseroan terbatas" ini sebagai ketentuan pembuatan akta pendirian Perseoran Terbatas. Pasal 2 ayat (1) Nomor 29 Tahun 2016 menjelaskan bahwa "Modal dasar Perseroan Terbatas sebagaimana dimaksud dalam Pasal 1 harus ditempatkan dan disetor penuh paling sedikit 25\% (dua puluh lima persen) yang dibuktikan dengan bukti penyetoran yang sah." Besaran modal dasar di anggaran dasar nantinya akan menjadi jumlah saham yang dapat diterbitkan oleh perseroan.

Perseroan Terbatas merupakan perusahaan yang didalamnya melakukan kegiatan perdagangan. Setiap perushaaan yang ingin melakukan kegiatan dalam bentuk perdagangan wajib untuk memiliki Surat Izin Usaha Perdangan (SIUP). Pasal 1 angka 4 Perautran Menteri Perdagangan Republik Indonesia Nomor 46/MDAG/PER/9/2009 tetang Perubahan Atas Peraturan Menteri Perdagangan Republik Indonesia Nomor 36/M-DAG/PER/9/2007 tentang Penerbitan Surat Izin Usaha Perdagangan menjelaskan "Surat Izin Usaha Perdagangan yang selanjutnya SIUP adalah Surat Ijin untuk dapat melaksanakan kegiatan usaha, yang selanjutnya disebut SIUP." Pengeritan lainnya dari Surat Izin Usaha Perdangan adalah surat izin yang

\footnotetext{
3 Harahap, A. S. (2008). Tanggung Jawab Direksi dalam Kepailitan Perseroan Terbatas. Lex Jurnalica, 5(3), hlm 159.
} 
diberikan oleh lemabaga yang berwenang untuk itu (dalam hal ini Menteri Perdagangan) untuk melaksanakan kegiatan usahanya di bidang jasa dan perdagangan. ${ }^{4}$

Membuat Surat Izin Usaha Perdagangan sesuai dengan Peraturan tersebut diatur dalam Pasal 3 ayat (1) Peraturan Menteri Perdagangan Republik Indonesia Nomor 46/M-DAG/PER/9/2009 tentang Penerbitan Surat Izin Usaha Perdagangan untuk "SIUP Kecil wajib dimiliki oleh perusahaan perdagangan yang kekayaan bersihnya lebih dari Rp 50.000.000, (lima puluh juta rupiah) sampai dengan paling banyak Rp 500.000.000, (lima ratus juta rupiah) tidak termasuk tanah dan bangunan tempat usaha." Pengecualian untuk tidak memiliki SIUP diberikan kepada beberapa perusahaan, yaitu:

1. Cabang/perwakilan perusahaan

2. Izin diperoleh dari departemen teknik dan tidak melakukan kegiatan perdagangan.

3. Perusahaan produksi.

4. Perjan dan perum.

5. Perusahaan kecil perseorangan. ${ }^{5}$

Ketentuan tersebut sesuai dengan ketentuan Pasal 4 ayat (1) Peraturan Menteri Perdagangan Republik Indonesia Nomor 46/M-DAG/PER/9/2009. SIUP memiliki 3 (tiga) jenis yang diatur dalam Pasal 2 ayat (2) Perautran Menteri Perdagangan Republik Indonesia Nomor 46/M-DAG/PER/9/2009 yaitu:

1. SIUP Kecil;

2. SIUP Menengah; dan

3. SIUP Besar.

Penjelasan Jenis-jenis tersebut diatur dalam Pasal 3 Perautran Menteri Perdagangan Republik Indonesia Nomor 46/M-DAG/PER/9/2009. Pasal 3 ayat (1) menjelaskan bahwa "Surat Izin Usaha Perdagangan Kecil adalah perusahaan perdagangan yang kekayaan bersihnya lebih dari Rp. 50.000.000, (lima puluh juta rupiah) sampai dengan paling banyak Rp. 500.000.000, (lima ratus juta rupiah) tidak termasuk tanah dan bangunan tempat usaha." Pasal 3 ayat (2) menjelaskan bahwa "Surat Izin Usaha Perdagangan Menengah adalah perusahaan perdagangan yang kekayaan bersihnya lebih dari Rp. 500.000.000, (lima ratus juta rupiah) sampai dengan paling banyak Rp. 10.000.000.000, (sepuluh milyar rupiah) tidak termasuk tanah dan bangunan tempat usaha." Dan Pasal 3 ayat (3) menjelaskan bahwa "Surat Izin Usaha Perdaganagn Besar adalah perusahaan perdagangan yang kekayaan bersihnya lebih dari Rp. 10.000.000.000, (sepuluh milyar rupiah) tidak termasuk tanah dan bangunan tempat usaha."

Dari latarbelakang tersebut timbul konflik norma mengenai biaya awal yang wajib disetorkan untuk membuat Perseroan Terbatas (PT). Peraturan Pemerintah Nomor 29 Tahun 2016 tentang Perubahan Modal Dasar Perseroan Terbatas yang tercantum pada Pasal 1 ayat (3) menyebutkan bahwa "besaran modal dasar Perseroan Terbatas sebagaimana dimaksud pada ayat (1) ditentukan berdasarkan kesepakatan pendiri

\footnotetext{
${ }^{4}$ Lesmana, R. A. (2016). Mekanisme Pelayanan Surat Izin Usaha Perdagangan (SIUP) Pada Badan Pelayanan Perizinan Terpadu Satu Pintu (BPPTSP) Kota Samarinda. Jurnal Administrasi Negara, (2), hlm 4110.

${ }^{5}$ Saliman, R Abdul, 2015, Hukum Bisnis Untuk Perusahaan : Teori dan Contoh Kasus, Kencana, Jakarta, hlm 104.
} 
perseroan terbatas". Peraturan tersebut menjelaskan bahwa, para pihak perseroan bebas menentukan modal dasar untuk mendirikan suatu perseroan terbatas. Sedangkan Pada Pasal 3 ayat (1) Peraturan Menteri Perdagangan Republik Indonesia Nomor 46/M-DAG/PER/9/2009 mengenai "SIUP Kecil adalah perusahaan perdagangan yang kekayaan bersihnya lebih dari Rp. 50.000.000, (lima puluh juta rupiah) sampai dengan paling banyak Rp. 500.000.000, (lima ratus juta rupiah) tidak termasuk tanah dan bangunan tempat usaha". Pasal ini menjelaskan untuk mendirikan suatu perseroan terbatas, wajib untuk memiliki modal awal sejumlah $\mathrm{Rp} 50.000 .000$ (lima puluh juta rupiah). Dari latarbelakang tersebut dapat dibuat dua rumusan masalah yaitu Bagaimanakah Proses Pendirian Persoran Terbatas dan Bagaimanakah Implikasi Hukum Pendirian Perseoran Terbatas Dalam Membuat Surat Izin Usaha Perdagangan dengan Peraturan Pemerintah Nomor 29 Tahun 2016. Sehingga dalam penelitian ini, menggunakan judul "Pengaturan Pembuatan Surat Izin Usaha Perdagangan Dalam Pendirian Perseroan Terbatas Dengan Terbitnya Peraturan Pemerintah Nomor 29 Tahun 2016."

\section{Metode Penelitian}

Metode penelitian hukum digunakan dalam penlitian ini sebagai suatu langkah terstruktur untuk membuat suatu penelitian. ${ }^{6}$ Metode yang dipakai adalah penelitian hukum normatif. Permasalah ini membahas mengenai konflik norma yang terjadi antara Pasal 1 ayat (3) Peraturan Pemerintah Nomor 29 Tahun 2016 tentang Perubahan Modal Dasar Perseroan Terbatas dengan Pasal 3 ayat (1) Peraturan Menteri Perdagangan Republik Indonesia No 49 Tahun 2009 tentang Penerbitan Surat Izin Usaha Perdagangan mengenai Pendirian Usaha (Perseroan Terbatas). Pendeketan dalam penelitian ini dilakukan dengan pendekatan undang-undang (Statute Approach) dan pendekatan analisis konsep hukum (Analitical and Conseptual Approach). Sumber hukum dalam penelitian ini bersumber dari bahan hukum primer dan bahan hukum sekunder. Teknik pengumpulan bahan hukum dalam penelitian ini berupa mencatat mengumpulkan bahan-bahan tersebut lalu memilah-milah bahan yang tepat untuk dimasukan dalam penelitian ini (card system) dan teknik analisis bahan hukum yang digunakan adalah teknik deskripsi, teknik evaluasi dan teknik argumentasi.

\section{Hasil dan Pembahasan}

\subsection{Proses pendirian Perseroan Terbatas (PT)}

Pendirian suatu Perseroan Terbatas, harus melalui beberapa tahapan-tahapn yang wajib untuk diselesaikan, sehingga Perseroan Terbatas tersebut dapat beroprasi/berpraktek di suatu wilayah. Isitlah Perseroan Terbatas merupakan gabungan dari kata perseroan yaitu saham-saham yang merupakan modal dari Perseroan Terbatas dan kata terbatas yaitu tanggung jawab sebatas jumlah saham yang disetorkan perseoran. 7 Pendirian Perseroan Terbatas dalam Undang-Undang Perseroan Terbatas tahun 2007 diatur di dalam Pasal 7 sampai dengan Pasal 14. Pasal 7 ayat (2) Undang-undang Perseroan Terbatas 2007, menjelaskan bahwa "Perseroan

\footnotetext{
${ }^{6}$ Abdulkadir Muhammad, 2004, Hukum dan Penelitian Hukum, PT. Citra Aditya Bakti, Bandung, hlm 57.

${ }^{7}$ Khairandy, R. (2013). Karakter Hukum Perusahaan Perseroan dan Status Hukum Kekayaan yang Dimilikinya. Ius Quia Iustum Law Journal, 20(1), 81-97, hlm 87.
} 
didirikan minimal oleh 2 (dua) orang atau lebih dengan akta notaris yang dibuat dalam bahasa Indonesia". Dilihat dari prinsip perseroan terbatas yang merupakan badan hukum, wajib untuk dibuat dengan kesepakatan oleh 2 (dua) orang atau lebih. Perseroan Terbatas merupakan badan hukum yang memiliki hak dan kewajibannya sama dengan orang sebagai subyek hukum. ${ }^{8}$ Istilah "orang: yang dimaksud dalam undang-undang ini, adalah orang perseorangan, baik warga negara Indonesia maupun luar Indonesia atau badan hukum Indonesia atau luar Indonesia.

Pengertian Perseroan Terbatas diatur dalam Pasal 1 ayat 1 Undang-Undang Nomor 40 Tahun 2007 tentang Perseroan Terbatas yang menjelaskan bahwa "Perseroan Terbatas, yang selanjutnya disebut perseroan, adalah badan hukum yang merupakan persekutuan modal, didirikan berdasarkan perjanjian, melakukan kegiatan usaha dengan modal dasar yang sulurhnya terbagi dalam saham dan memenuhi perysaratan yang ditetapkan dalam undang-undang ini serta peraturan pelaksananya." Pendirian suatu Perseroan Terbatas, wajib untuk menyelesaikan beberapa tahapan-tahapan seusai dengan ketentuan yang berlaku, sehingga Perseroan Terbatas tersebut dapat beroperasi/berpraktek di suatu wilayah. Ketentuan pendirian Perseroan Terbatas telah cantumkan dalam Undang-Undang Perseroan Terbatas tahun 2007 yang diatur di dalam Pasal 7 Undang-undang Perseroan Terbatas 2007 menjelaskan sebagai berikut:

1. Perseroan didirikan oleh 2 (dua) orang atau lebih dengan akta notaris yang dibuat dalam Bahasa Indonesia.

2. Setiap pendiri Perseroan wajib mengambil bagian saham pada saat Perseroan didirikan.

3. Ketentuan sebagaimana dimaksud pada ayat (2) tidak berlaku dalam rangka Peleburan.

4. Perseroan memperoleh status badan hukum pada tanggal diterbitkannya keputusan menteri mengenai pengesahan badan hukum Perseroan.

5. Setelah Perseroan memperoleh status badan hukum dan pemegang saham menjadi kurang dari 2 (dua) orang, dalam jangka waktu paling lama 6 (enam) bulan terhitung sejak keadaan tersebut pemegang saham yang bersangkutan wajib mengalihkan sebagian sahamnya kepada orang lain atau Perseroan mengeluarkansaham baru kepada orang lain.

6. Dalam hal jangka waktu sebagaimana dimaksud pada ayat (5) telah dilampaui, pemegang saham tetap kurang dari 2 (dua) orang, pemegang saham bertanggung jawab secara pribadi atas segala perikatan dan kerugian Perseroan, dan atas permohonan pihak yang berkepentingan, pengadilan negeri dapat membubarkan Perseroan tersebut.

7. Ketentuan yang mewajibkan Perseroan didirikan oleh 2 (dua) orang atau lebih sebagaimana dimaksud pada ayat (1), dan ketentuan pada ayat (5), serta ayat (6) tidak berlaku bagi:

a. Persero yang seluruh sahamnya dimiliki oleh negara; atau

b. Perseroan yang mengelola bursa efek, lembaga kliring dan penjaminan, lembaga penyimpanan dan penyelesaian, dan lembaga lain sebagaimana diatur dalam undangundang tentang Pasar Modal.

\footnotetext{
${ }^{8}$ Budiono, H. (2012). Arah Pengaturan Undang-Undang Nomor 40 Tahun 2007 Tentang Perseroan Terbatas Dalam Menghadapi Era Global. Jurnal Rechts Vinding: Media Pembinaan Hukum Nasional, 1(2), 187-198, hlm 189.
} 
Selanjutnya pada Pasal 8 Undang-undang Perseroan Terbatas 2007 menjelaskan mengenai prihal akta pendirian Perseroan Terbatas sebagai berikut:

1. Akta pendirian memuat anggaran dasar dan keterangan lain berkaitan dengan pendirian Perseroan.

2. Keterangan lain sebagaimana dimaksud pada ayat (1) memuat sekurangkurangnya:

a. nama lengkap, tempat dan tanggal lahir, pekerjaan, tempat tinggal, dan kewarganegaraan pendiri perseorangan, atau nama, tempat kedudukan dan alamat lengkap serta nomor dan tanggal keputusan menteri mengenai pengesahan badan hukum dari pendiri Perseroan;

b. nama lengkap, tempat dan tanggal lahir, pekerjaan, tempat tinggal, kewarganegaraan anggota Direksi dan Dewan Komisaris yang pertama kali diangkat;

c. nama pemegang saham yang telah mengambil bagian saham, rincian jumlah saham, dan nilai nominal saham yang telah ditempatkan dandisetor.

3. Dalam pembuatan akta pendirian, pendiri dapat diwakili oleh orang lain berdasarkan surat kuasa.

Setelah membuat akta pendirian, perseroan terbatas wajib mendapatkan pengesahan dari menteri sebagaimana diatur dalam Pasal 9 Undang-undang Perseroan Terbatas 2007 menjelaskan bahwa:

1. Untuk memperoleh keputusan menteri mengenai pengesahan badan hukum Perseroan sebagaimana dimaksud dalam Pasal 7 ayat (4), pendiri bersama-sama mengajukan permohonan melalui jasa teknologi informasi sistem administrasi badan hukum secara elektronik kepada Menteri dengan mengisi format isian yang memuat sekurang-kurangnya:
a. nama dan tempat kedudukan Perseroan;
b. jangka waktu berdirinya Perseroan;
c. maksud dan tujuan serta kegiatan usaha Perseroan;
d. jumlah modal dasar, modal ditempatkan, dan modal disetor;
e. alamat lengkap Perseroan.

2. Pengisian format isian sebagaimana dimaksud pada ayat (1) harus didahului dengan pengajuan nama Perseroan.

3. Dalam hal pendiri tidak mengajukan sendiri permohonan sebagaimana dimaksud pada ayat (1) dan ayat (2), pendiri hanya dapat memberi kuasa kepada notaris.

4. Ketentuan lebih lanjut mengenai tata cara pengajuan dan pemakaian nama Perseroan diatur dengan peraturan pemerintah.

Proses pengajuan untuk memperoleh pengesahan oleh menteri diatur dalam Pasal 10 Undang-undang Perseroan Terbatas 2007 yang menjelaskan sebagai berikut:

1. Permohonan untuk memperoleh keputusan menteri sebagaimana dimaksud dalam Pasal 9 ayat (1) harus diajukan kepada Menteri paling lambat 60 (enam 
puluh) hari terhitung sejak tanggal akta pendirian ditandatangani, dilengkapi keterangan mengenai dokumen pendukung.

2. Ketentuan mengenai dokumen pendukung sebagaimana dimaksud pada ayat (1) diatur dengan peraturan menteri.

3. Apabila format isian sebagaimana dimaksud dalam Pasal 9 ayat (1) dan keterangan mengenai dokumen pendukung sebagaimana dimaksud pada ayat (1) telah sesuai dengan ketentuan peraturan perundang-undangan, Menteri langsung menyatakan tidak berkeberatan atas permohonan yang bersangkutan secara elektronik.

4. Apabila format isian sebagaimana dimaksud dalam Pasal 9 ayat (1) dan keterangan mengenai dokumen pendukung sebagaimana dimaksud pada ayat (1) tidak sesuai dengan ketentuan peraturan perundang-undangan, Menteri langsung memberitahukan penolakan beserta alasannya kepada pemohon secara elektronik.

5. Dalam jangka waktu paling lambat 30 (tiga puluh) hari terhitung sejak tanggal pernyataan tidak berkeberatan sebagaimana dimaksud pada ayat (3), pemohon yang bersangkutan wajib menyampaikan secara fisik surat permohonan yang dilampiri dokumen pendukung.

6. Apabila semua persyaratan sebagaimana dimaksud pada ayat (5) telah dipenuhi secara lengkap, paling lambat 14 (empat belas) hari, Menteri menerbitkan keputusan tentang pengesahan badan hukum Perseroan yang ditandatangani secara elektronik.

7. Apabila persyaratan tentang jangka waktu dan kelengkapan dokumen pendukung sebagaimana dimaksud pada ayat (5) tidak dipenuhi, Menteri langsung memberitahukan hal tersebut kepada pemohon secara elektronik, dan pernyataan tidak berkeberatan sebagaimana dimaksud pada ayat (3) menjadi gugur.

8. Dalam hal pernyataan tidak berkeberatan gugur, pemohon sebagaimana dimaksud pada ayat (5) dapat mengajukan kembali permohonan untuk memperoleh keputusan menteri sebagaimana dimaksud dalam Pasal 9 ayat (1).

9. Dalam hal permohonan untuk memperoleh keputusan menteri tidak diajukan dalam jangka waktu sebagaimana dimaksud pada ayat (1), akta pendirian menjadi batal sejak lewatnya jangka waktu tersebut dan Perseroan yang belum memperoleh status badan hukum bubar karena hukum danpemberesannya dilakukan oleh pendiri.

10. Ketentuan jangka waktu sebagaimana dimaksud pada ayat (1) berlaku juga bagi permohonan pengajuan kembali.

Dan pada Pasal 11 Undang-undang Perseroan Terbatas 2007 menjelaskan mengenai "Ketentuan lebih lanjut mengenai pengajuan permohonan untuk memperoleh keputusan menteri sebagaimana dimaksud dalam Pasal 7 ayat (4) bagi daerah tertentu yang belum mempunyai atau tidak dapat digunakan jaringan elektronik diatur dengan peraturan menteri." Penjelesan pendirian Perseroan terbatas tersebut berdasarkan ketentuan Undang-undang Perseroan Terbatas. 
Pembuatan akta pendirian Perseroan Terbatas memiliki ketentuan-ketentuan yang wajib untuk dilengkapi sesuai dengan peraturan yang berlaku. Secara praktik penelitian ini telah melakukan wawancara dengan Putu Rick Anjasmara, selaku staff di kantor Notaris I Ketut Mustika Udaya, SH. sebagai sumber pendukung penenelitian ini untuk mengetahui peroses mendirikan perseroan secara praktik. Pendiri perseroan wajib untuk melakukan langkah-langkah sebagai berikut:

1. Memesan nama Perseroan terlebih dahulu melalui sistem online di web https://www.ahu.go.id

2. Setelah disetujui baru dilakukan pembuatan akta pendirian Perseroan Terbatas.

3. Perseroan wajib untuk menentukan bidang usaha dengan Klarifikasi Baku Lapangan Usaha Indonesia (KBLI) tahun 2017 untuk memilih kode bidang usaha yang dijalankan.

4. Para pendiri Perseroan Terbatas wajib memiliki Nomor Pokok Wajib Pajak (NPWP). untuk mendirikan suatu perseroan, NPWP perusahaan mutlak dimiliki pendiri persero. Untuk membuat NPWP pendiri persero memerlukan salinan akta perusahaan dan surat keterangan domisili.

5. Menentukan Modal Dasar dan Pengurus Perseroan Terbatas

6. Setelah semua terpenuhi baru dilakukan pendaftarkan melalui online di web https://www.ahu.go.id

7. Membuat Surat Izin Usaha Perdagangan sebagai bagian dari proses mendirikan Perseroan Terbatas agar perusahaan dapat beroperasi.

8. Mengurus Tanda Daftar Perusahaan. (Hasil wawancara pada hari sabtu tanggal 2 Juni 2019).

\subsection{Implikasi Hukum Pendirian Perseoran Terbatas Dalam Membuat Surat Izin Usaha Perdagangan dengan Peraturan Pemerintah Nomor 29 Tahun 2016.}

Perseroan Terbatas adalah badan hukum yang merupakan persekutuan modal, didirikan berdasarkan perjanjian, melakukan kegiatan usaha dengan modal dasar yang seluruhnya terbagi dalam saham dan memenuhi persyaratan yang ditetapkan dalam undang-undang ini serta peraturan pelaksanaannya. Persesroan Terbatas memiliki kelebihan yaitu bertanggung jawab sebatas dana yang telah dikumpulkan dalam perseroannya saja. Dari kelebihannya perseroan memiliki kekurangan yaitu salah satunya adalah biaya pendiriannya yang mahal. Oleh karena itu, pemerintah memberikan kemudahan dengan menerbitkan Peraturan Pemerintah Nomor 29 Tahun 2016 tentang Perubahan Modal Dasar Perseroan Terbatas modal dasar pendirian perseoran terbatas. Terbitnya Peraturan Pemerintah Nomor 29 Tahun 2016 memberikan kebebasan bagi para pendiri perseroan dalam menentukan bersaran modal dasar Perseroan Terbatas yang diatur dalam Pasal 1 ayat (3) Peraturan Pemerintah Nomor 29 Tahun 2016. Pasal tersebut menjelaskan bahwa “Besaran modal dasar Perseroan Terbatas sebagaimana dimaksud pada ayat (1) ditentukan berdasarkan kesepakatan para pendiri Perseroan Terbatas".

Peraturan Pemerintah Nomor 29 Tahun 2016 tersebut dapat menimbulkan masalah dalam membuat Surat Ijin Usaha Perdagangan. Dikarenakan untuk membuat Surat Ijin Usaha Perdagangan, perseroan terbatas wajib memiliki modal dasar minimal Rp 50.000.000 (lima puluh juta rupiah) sebagaimana diatur dalam Pasal 3 ayat (1) 
Peraturan Menteri Perdagangan Republik Indonesia Nomor 46/M-DAG/PER/9/2009 tentang Penerbitan Surat Izin Usaha Perdagangan untuk "SIUP Kecil wajib dimiliki oleh perusahaan perdagangan yang kekayaan bersihnya lebih dari Rp 50.000.000, (lima puluh juta rupiah) sampai dengan paling banyak Rp 500.000.000, (lima ratus juta rupiah) tidak termasuk tanah dan bangunan tempat usaha." Sehingga perseroan terbatas menjadi bermasalah apabila kesepakatan modal dasar para pendiri perseroan terbatas dibawah Rp. 50.000 .000 (lima puluh juta rupiah). Dari penjelasan tersebut menimbulkan konflik norma antara Peraturan Pemerintah Nomor 29 Tahun 2016 dengan Peraturan Menteri Perdagangan Republik Indonesia Nomor 46/MDAG/PER/9/2009.

Timbulnya konflik norma antara Peraturan Pemerintah No 29 Tahun 2016 dengan Perautran Menteri Perdagangan Republik Indonesia Nomor 46/M-DAG/PER/9/2009 dapat diselesaikan dengan menggunakan asas preferensi atau disebut juga asas penyelesaian konflik, dengan menggunakan identifikasi aturan hukum yang dalam keadaan kekosongan hukum (leemten in het recht), konflik antara norma hukum (antinomi hukum), dan norma yang kabur (vage normen) atau norma tidak jelas. Dalam penelitian ini, untuk menjawab suatu konflik norma terkait peraturan perundangundang dipergunakan Asas preferensi. Asas preferensi dipecah menjadi tiga asas yaitu asas lex superior derogate legi inferiori, yaitu asas yang menggunakan peraturan tingkatannya lebih tinggi dan menyampingkan peraturan yang lebih rendah berdasarkan hirarki peraturan perundang-undangan. Selanjutnya asas lex spesialis derogate legi generali, yaitu asas yang menggunakan peraturan yang bersifat khusus dan menyampingkan yang bersifat umum. Dan yang terakhir adalah asas lex posterior derogate legi priori yaitu menggunkan peraturan baru dan menyampingkan peraturan lama.

Untuk permasalahan ini dipergunakan Asas Lex superior derogat legi inferiori yang menjelaskan bahwa peraturan perundang-undangan yang lebih tinggi tingkatannya mengenyampingkan berlakunya peraturan perundang-undang yang lebih rendah tingkatannya. Mengenai tinggi atau rendahnya tingkatan peraturan perundangundangan dapat dilihat dalam Undang-Undang Nomor 12 Tahun 2011 tentang Pembentukan Peraturan Perundang-Undangan yang menjelaskan terkait hierarki peraturan perundang-undangan. Pada Pasal 7 menjelaskan bahwa jenis dan hierarki Peraturan Perundang-Undangan terdiri atas:

a. Undang-Undang Dasar Negara Republik Indonesia Tahun 1945;

b. Ketetapan Majelis Permusyawaratan Rakyat;

c. Undang-Undang/Peraturan Pemerintah Pengganti Undang-Undang;

d. Peraturan Pemerintah;

e. Peraturan Presiden;

f. Peraturan Daerah Provinsi; dan

g. Peraturan Daerah Kabupaten/Kota.

Peraturan Pemerintah Nomor 29 Tahun 2016 tercantum pada hierarki yang dijelaskan pada Pasal 7 Undang-Undang No 12 Tahun 2011 sedangkan Peraturan Menteri Perdagangan Republik Indonesia Nomor 46/M-DAG/PER/9/2009 tidak tercantum dalam Hierarki pada Pasal 7, namun disebutkan dalam Pasal 8 ayat (1) Undang- 
Undang Nomor 12 Tahun 2011 yang disebutkan bahwa "jenis Peraturan Perundangundangan selain sebagaimana dimaksud dalam Pasal 7 ayat (1) mencangkup peraturan yang ditetapkan oleh Majelis Permusyawaratan Rakyat, Dewan Perwakilan Rakyat, Dewan Perwakilan Daerah, Mahkamah Agung, Mahkamah Konstitusi, Badan Pemeriksa Keuangan, Komisi Yudisial, Bank Indonesia, Menteri, badan, lembaga, atau komisi yang setingkat yang dibentuk dengan Undang-Undang atau Pemerintah atas perintah Undang-Undang, Dewan Perwakilan Rakyat Daerah Provinsi, Gubernur, Dewan Perwakilan Rakyat Daerah Kabupaten/Kota, Bupati/Walikota, Kepala Desa atau yang setingkat."

Tingakatan peraturan menteri dibawah dari Peraturan Pemerintah sebagaimana penjelasan Pasal 8 ayat (2) Undang-Undang Nomor 12 Tahun 2011 menyebutkan bahwa Peraturan yang diatur di Pasal 8 ayat (1) diakui eksistensinya dan memiliki kekuatan hukum selama merupakan printah dari Peraturan yang lebih tinggi atau dibentuk berdasarkan kewenangan. ${ }^{9}$ Dengan menggunkan Asas Lex superior derogat legi inferiori menjelaskan bahwa Peraturan Pemerintah Nomor 29 Tahun 2016 menyampingkan Peraturan Menteri Perdagangan Republik Indonesia Nomor 46/MDAG/PER/9/2009. Sehingga implikasi hukum pendirian Perseoran Terbatas dalam membuat Surat Izin Usaha Perdagangan dengan Peraturan Pemerintah nomor 29 tahun 2016 adalah para pendiri Perseroan Terbatas dapat membuat SIUP dengan modal dasar kesepakatan para pendiri perseroan.

\section{Kesimpulan}

Peroses pendirian perseroan terbatas dilakukan dengan cara memesan nama perseroan terlebih dahulu melalui sistem online di web https://www.ahu.go.id. Setelah disetujui baru dilakukan pembuatan akta pendirian Perseroan Terbatas dengan syarat yaitu didirikan oleh dua orang atau lebih (kecuali BUMN). Perseroan wajib untuk menentukan bidang usaha dengan Klarifikasi Baku Lapangan Usaha Indonesia (KBLI) tahun 2017 yang merupakan pengklasifikasi untuk memilih kode bidang usaha yang dijalankan. Para pendiri Perseroan Terbatas wajib memiliki Nila Pokok Wajib Pajak (NPWP). untuk mendirikan suatu perseroan, NPWP perusahaan mutlak dimiliki pendiri persero. Untuk membuat NPWP pendiri persero memerlukan salinan akta perusahaan dan surat keterangan domisili. Menentukan Modal Dasar dan Pengurus Perseroan Terbatas. Setelah semua terpenuhi baru dilakukan pendaftarkan melalui online di web https://www.ahu.go.id. Membuat Surat Izin Usaha Perdagangan dan membuat Tanda Daftar Perusahaan yang merupakan salah satu tata cara mendirikan Perseroan Terbatas agar perusahaan dapat beroperasi.

Timbulnya konflik norma antara Peraturan Pemerintah No 29 Tahun 2016 dengan Perautran Menteri Perdagangan Republik Indonesia Nomor 46/M-DAG/PER/9/2009 dapat diselesaikan dengan menggunakan asas preferensi atau disebut juga asas penyelesaian konflik, dengan menggunakan identifikasi aturan hukum yang dalam keadaan kekosongan hukum, konflik antara norma hukum, dan norma yang kabur atau norma tidak jelas. Dengan menggunkan Asas Lex superior derogat legi inferiori menjelaskan bahwa Peraturan Pemerintah Nomor 29 Tahun 2016 menyampingkan Peraturan Menteri Perdagangan Republik Indonesia Nomor 46/M-DAG/PER/9/2009.

\footnotetext{
${ }^{9}$ Saraswati, R. (2013). Problematika Hukum Undang-Undang No. 12 Tahun 2011 tentang Pembentukan Peraturan Perundangundangan. Jurnal Yustisia, 2(3), hlm 101.
} 
Sehingga implikasi hukum pendirian Perseoran Terbatas dalam membuat Surat Izin Usaha Perdagangan dengan Peraturan Pemerintah Nomor 29 Tahun 2016 adalah para pendiri perseroan terbatas dapat membuat SIUP dengan modal dasar kesepakatan para pendiri perseroan.

\section{Daftar Pustaka}

\section{Buku}

Abdulkadir Muhammad (2004) Hukum dan Penelitian Hukum, Bandung: PT. Citra Aditya Bakti.

Saliman, R Abdul (2015) Hukum Bisnis Untuk Perusahaan: Teori dan Contoh Kasus, Jakarta: Kencana.

\section{Jurnal}

Anand, G. (2012). AKIBAT HUKUM SAHAM YANG DIKELUARKAN PERSEORAN TANPA TERLEBIH DAHULU DITAWARKAN KEPADA PEMEGANG SAHAM. Yuridika, 27(3), 233-244.

Budiono, H. (2012). Arah Pengaturan Undang-Undang Nomor 40 Tahun 2007 Tentang Perseroan Terbatas Dalam Menghadapi Era Global. Jurnal Rechts Vinding: Media Pembinaan Hukum Nasional, 1(2), 187-198.

Harahap, A. S. (2008). Tanggung Jawab Direksi dalam Kepailitan Perseroan Terbatas. Lex Jurnalica, 5(3).

Isfardiyana, S. H. (2015). Tanggung Jawab Direksi Perseroan Terbatas dalam Pelanggaran Fiduciary Duty. Padjadjaran Journal of Law, 2(1).

Khairandy, R. (2013). Karakter Hukum Perusahaan Perseroan dan Status Hukum Kekayaan yang Dimilikinya. Ius Quia Iustum Law Journal, 20(1), 81-97.

Lesmana, R. A. (2016). Mekanisme Pelayanan Surat Izin Usaha Perdagangan (SIUP) Pada Badan Pelayanan Perizinan Terpadu Satu Pintu (BPPTSP) Kota Samarinda. Jurnal Administrasi Negara, (2).

Saraswati, R. (2013). Problematika Hukum Undang-Undang No. 12 Tahun 2011 tentang Pembentukan Peraturan Perundangundangan. Jurnal Yustisia, 2(3).

Simanjuntak, A. (2011). Prinsip-prinsip manajemen bisnis keluarga (family business) dikaitkan dengan kedudukan mandiri perseroan terbatas (PT). Jurnal manajemen dan kewirausahaan, 12(2), 113-120.

\section{Peraturan Perundang-udangan}

Republik Indonesia, 2007, Undang-Undang Republik Indonesia Nomor 40 Tahun 2007 Tentang Perseroan Terbatas, (Lembaran Negara Republik Indonesia Tahun 2007 Nomor 106, Tambahan Lembaran Negara Republik Indonesia Nomor 4756).

Republik Indonesia, 2011, Undang-Undang Republik Indonesia Nomor 12 Tahun 2011 Tentang Pembentukan Peraturan Perundang-Undangan (Lembaran Negara Republik Indonesia Tahun 2011 Nomor 82, Tambahan Lembaran Negara Republik Indonesia Nomor 5234).

Republik Indonesia, 2009, Peraturan Menteri Perdagangan Republik Indonesia Nomor: 46/M-DAG/PER/9/2009 Tentang Perubahan Atas Peraturan Menteri Perdagangan Republik Indonesia Nomor 36/M-DAG/PER/9/2007 Tentang Penerbitan Surat Izin Usaha Perdagangan. 